DOI https://doi.org/10.18551/rjoas.2020-12.05

\title{
CONFIRMATORY FACTOR ANALYSIS OF SOCIAL SUPPORT TYPES FOR WORKERS WITH DISABILITIES IN SEMARANG
}

\author{
Sumarno Ginung Nurtyasto*, Akhyar Muhammad, Irianto Heru \\ Department of Postgraduate Extension Education, Sebelas Maret University, Indonesia \\ ${ }^{*}$ E-mail: ginunknurtyasto@gmail.com
}

\begin{abstract}
Workers with disabilities in Indonesia who work in formal sector employment are $34.45 \%$, this is much lower than non-disabled who work in the formal sector up to $50.73 \%$. There was about a $16.28 \%$ difference in formal employment access inequality. People with disabilities tend to work in non-formal sectors such as self-employed, self-employed with temporary/unpaid workers, unpaid workers, family workers. The main reason for that low distribution of workers with disabilities in the formal sector is adapting to a labour market competitiveness with all their physical limitations. Therefore, social support from all parties to people with disabilities is needed to compete and adapt in the formal employment sector. This study aims to test the validity and reliability determinants of social support types for workers with disabilities. The research subjects were workers with physical disabilities in Semarang, Indonesia. The research method was a quantitative descriptive analysis. Survey data collection with a sample of 150 respondents. Data analysis using CFA (Confirmatory Factor Analysis) with data processing tools using Lisrel 8.8. The results showed that $p$-value chi-square $=0,159 ;$ RMSEA $=0,075 ; \mathrm{CFI}=1,00$ means model good fit. The loading factors of all variables are $>0,5$ means positively significant. The conclusion proves that emotional support, instrumental support, informational support, and appraisal support were valid and reliable determining indicators of social support for workers with disabilities.
\end{abstract}

\section{KEY WORDS}

Disability workers, social inequality, social support, employment, confirmatory factor analysis, inclusive development.

Semarang City is the capital of Central Java Province, Indonesia. As one of the most developed cities in Java, Semarang has 1.814 .110 people within $373.8 \mathrm{~m} 2$ (BPS, 2020). Based on the Dinas Sosial Kota Semarang data survey in 2019, there are 5712 people with disabilities spread in Semarang's 16 sub-districts. The local government seeks to empower people with disabilities in the region by implementing Peraturan Gubernur (Pergub) of Central Java Province no. 11 of 2017 on The Regulation on The Fulfillment of The Rights of Persons with Disabilities. One of the agendas is to provide a quota for people with disabilities of at least $1 \%$ (one percent) of the employee for the private sector and $2 \%$ (two percent) for the public sector (government and state-owned enterprises).

Although there are already official government rules to provide quotas, only $34.45 \%$ of people with disabilities are absorbed in the formal sector, which is much lower than nondisabled people absorbed by up to $50.73 \%$ (ILO, 2017). There is a gap inequality of about $16,28 \%$. The problem is the company's lack of awareness to provide employment opportunities and adaptation of work people with disabilities. Due to the labor market's competitiveness, workers with disabilities must adapt to their work with all limitations (Purinami et al., 2019).

Based on these issues, it is necessary to play all parties' roles: government, companies, colleagues, etc., in looking at this issue and participating in "inclusive development" (Hastuti et al., 2019). "Development" is a process to promote the improvement of people's well-being in a broad sense-not only from the economic side, but also from the social, political, and health side (Kanbur \& Rauniyar, 2010). Meanwhile, "inclusive" means a condition that ensures all parties (without discrimination) as both an object and a subject. 
This engagement is not just to avoid conflict to make individuals/groups feel having and motivation to contribute.

This issue is interesting to review because when entering the workplace, people with disabilities are faced with the problem of self-adjustment to the new environment. Mainly related to interaction with non-disabilities and how the support of various stakeholders so that people with disabilities can open up access, enter, and adapt in the workplace.

In social interactions, persons with disabilities while in the work environment will be directly dealing with non-disabled people with different physical conditions and affect the psychological impact of workers with disabilities. Social support, in combination with certain personal factors, spurs adaptation to physical disability and can avoid the effects of environmental pressures (Swanson et al., 1989).

People with disabilities in adapting to the work environment are primarily based on social support (both instrumental and emotional) by supervisors and co-workers (Zreda \& Majewski, 2012). Therefore, efforts related to the work adaptation of workers with disabilities must be considered in terms of material expenditure and productivity of the company and preventing the social exclusion of people with disabilities in the environment. Another opinion reveals that workplace organizational support and family support are significant factors of job satisfaction of people with disabilities (Pérez et al., 2015).

Based on the background description, there is the formulation of research problems: What are the types of determining indicators of social support for workers with disabilities in Semarang?

\section{LITERATURE REVIEW}

Social support is a positive feeling, liking, trust, and attention of others, i.e., a meaningful person in the life of the individual concerned, recognition, the trust of a person, and direct assistance in a specific form (Cohen \& Wills, 1985). Social support refers to the various resources provided by a person's interpersonal relationships. Social support has a positive effect on health, which may be noticeable even when not under tremendous pressure. Social support is a protective factor that protects or protects individuals from physiological or psychological consequences of exposure stressor situation (Cassel, 1976). So it can be suspected that social support can protect individuals from social pressures that can hinder the process of adapting work.

Most theories about social support assume that the support provided is then received by members of the social network, leading to social integration and feelings of mutual having (Norbeck \& Tilden, 1983). Social support recipients' perception can encourage coping with stressors in their lives (Sarason et al., 1990). Shumaker \& Brownell (1984) defines social support as an exchange of resources between givers and recipients to improve well-being. Several characters affect quality and sufficiency, such as stability, direction, and support source (Stewart, 1989). Social networks can also be described from which parties provide support: family members, close friends, neighbors, co-workers, and professionals (Tardy, 1985).

In the context of employment organizations, perceived support from various sources of support in the organization (co-workers, supervisors, and the organization itself) is a critical factor in employee orientation towards the organization and its job duties, employee performance, employee welfare, and job satisfaction (Kurtessis et al., 2015). Perceived support from perceived families is another critical factor because it can create or compensate for workers' conflicts (Kossek et al., 2011).

Perceived support responds to how individuals view friends, family members, and others as sources to provide the material, psychological support needed. Consistently felt social support related to well-being, acceptance rate, love, and perceived attention could positively experience (Siedlecki et al., 2014).

Researchers tend to use social support by four construct theories, or definitions of attributes presented include emotional support, informational support, instrumental support, and appraisal support (Barrera, 1986; Deutsch \& House, 1983; Fleury et al., 2009; Langford 
\& May, 1994; Lysaght et al., 2012; Peterson \& Bredow, 2011; Tilden \& Weinert, 1987). These four attributes already include all possible acts of action in social support:

Emotional Support. Emotional support includes expressions of empathy, care, and attention that others give to individuals. When individuals feel empathy, care, and attention from others, they will feel not alone in facing problems or difficulties to bring forth their strength to overcome the difficulties it faces. Emotional support can include feeling liked, admired, respected, or loved. Related to the context of emotional support to workers with disabilities, for example:

- Employers provide consultation on wages and awards;

- Coworkers provide privacy when in need of;

- Colleagues care / ask how people with disabilities do their work;

- Families know the routines of people with disabilities;

- Families were supporting careers with disabilities.

Instrumental support. Instrumental support includes direct support or assistance in time, and other tangible assistance that others provide to individuals. Related to the context of instrumental support to workers with disabilities, for example:

- Supervisors respond quickly when an injury occurs;

- Employers ensure accommodation needs are provided and appropriate;

- Coworkers offer help at work;

- Coworkers offer off-the-job assistance;

- Family readiness to help if they need transportation.

Informational Support. Informational support includes support in providing advice, guidance, suggestion, feedback, and responses. This informative support makes it easier for individuals to expand their thinking or view of a problem. So that individuals can have many alternative solutions and can choose the most effective alternatives. Related to the context of information support to workers with disabilities, for example:

- Employers give tips at work;

- Coworkers share experience information;

- The family gives advice when experiencing problems.

Appraisal Support. Appraisal support includes positive expressions, forward-looking encouragement that others give to individuals, and favorable comparisons of individuals. The presence of positive expressions and encouragement from others helps the individual see their strengths, not only focusing on his shortcomings alone but also on progress. Thus, this support helps individuals to have a positive and optimistic attitude. Related to the context of assessment support to workers with disabilities, for example:

- Employers appreciate the efforts made;

- Employers assess as-is regardless of physical condition;

- Employers provide evaluations related to performance;

- Employers open career path opportunities.

Based on the literature review can be made some hypothesis which is the relationship between variables:

- Hypothesis 1: Emotional support is a valid and reliable determining indicator of the social support for workers with disabilities;

- Hypothesis 2: Instrumental support is a valid and reliable determining indicator of the social support for workers with disabilities;

- Hypothesis 3: Informational support is a valid and reliable determining indicator of the social support for workers with disabilities;

- Hypothesis 4: Appraisal support is a valid and reliable determining indicator of the social support for workers with disabilities.

\section{METHODS OF RESEARCH}

This type of research is quantitatively descriptive. Quantitative methods are suiTable for use when the problem is that the turning point of research is clear. The problem is an 
aberration between what should and what happens, between the rules and the implementation, between theory and practice, between the plan and the performance (Sugiyono, 2018). This research is based on the gap in disability access inequality in the formal sector. Then the ideal theory has been gathered to be tested in practice.

The study subjects were 602 workers with physical disabilities who worked in the formal sector in Semarang. Data retrieval by purposive proportional sampling with the data collection method using the questionnaire instrument. The sample size following SEM general provisions ranges from 100-200 respondents (Hair et al., 2010), then determined the sample size of the study of 150 respondents with physical disabilities (64 physically disabled, 85 deaf and 1 low vision). Data analysis techniques using CFA (Confirmatory Factor Analysis). Data analysis using Lisrel 8.8 analysis tool with the Robust Maximum Likelihood estimation method.

\section{RESULTS AND DISCUSSION}

Instruments in the form of questionnaires are tested first before conducting a full study. It aims to obtain reliability and validity of instruments, through 40 respondents of workers with physical disabilities. The questionnaire consisted of 20 statements in which each manifest variable had five statements. The data is processed using SPSS 26 , and the result of the 45 $r$ value $\geq r$ Table is $(r$ Table $=0.312)$, it means instrument items are valid as well as of all manifest variables. Then the value of Cronbach's alpha $\geq$ of 0.6 , which means a reliable instrument.

Table 1 - Instrument validity \& reliability test

\begin{tabular}{lllllll}
\hline \multirow{2}{*}{ Variable } & \multicolumn{2}{l}{ Validity Test } & & & & Reliability Test \\
\cline { 2 - 7 } & \multicolumn{2}{l}{ r value of items } & & & \multicolumn{3}{c}{ Cronbach's alpha } \\
\hline Emotional Support (X1) & X1.1 & X1.2 & X1.3 & X1.4 & X1.5 & 0,689 \\
& 0,816 & 0,392 & 0,650 & 0,739 & 0,738 & \\
\hline Instrumental Support (X2) & X2.1 & X2.2 & X2.3 & X2.4 & X2.5 & 0,657 \\
& 0,551 & 0,665 & 0,745 & 0,702 & 0,588 & \\
\hline Informational Support (X3) & X3.1 & X3.2 & X3.3 & X3.4 & X3.5 & 0,770 \\
& 0,763 & 0,772 & 0,752 & 0,482 & 0,856 & \\
\hline Appraisal Support (X4) & X4.1 & X4.2 & X4.3 & X4.4 & X4.5 & 0,768 \\
& 0,731 & 0,691 & 0,796 & 0,910 & 0,666 & \\
\hline
\end{tabular}

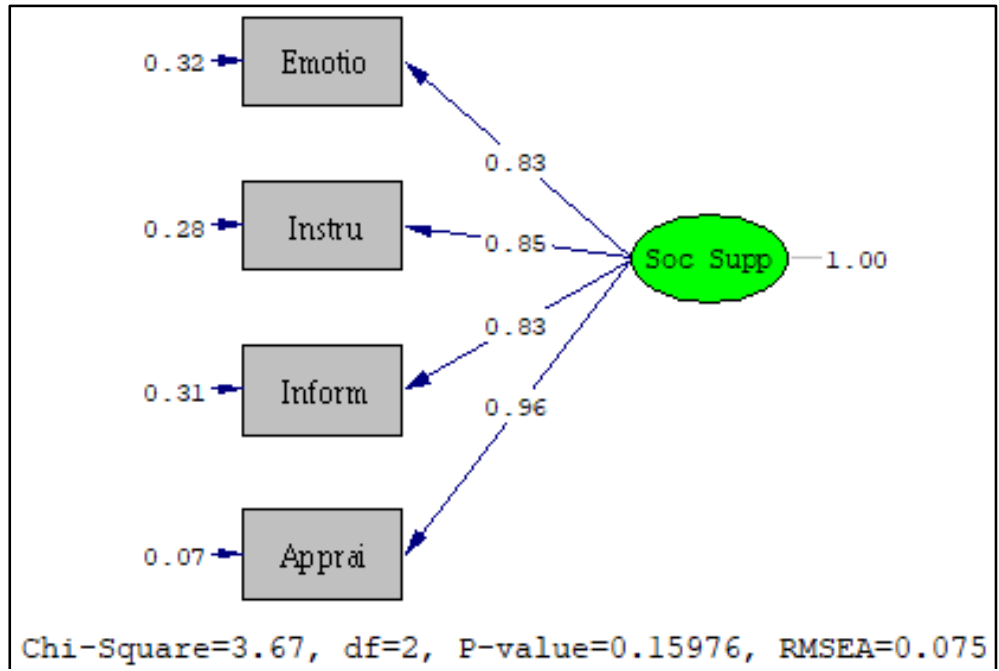

Figure 1 - Confirmatory factor analysis path diagram (Source: primary data processed, 2020)

After data retrieval of 150 respondents, then input data and normality test. Suppose multivariate data is non-normal or significant when it has a p-value of skewness and kurtosis $\leq 0.05$, while the assumption of multivariate normality is accepTable when the $p$-value $\geq 0.05$. 
Normality test results using Lisrel 8.8 show $p$-value $=0.000$, which means non-normal multivariate data. However, when viewed from skewness results $=2,244$ and kurtosis $=$ 2,511 indicates that the data is moderately non-normal because $2 \leq$ skewness $\leq 3$; Kurtosis $\leq$ 21 (Curran et al., 1996).

If the multivariate data is moderately non-normal, then Confirmatory Factor Analysis with the Maximum Likelihood (ML) estimation method cannot be used, so it is necessary to use the Robust Maximum Likelihood (RML) estimation method. Lisrel 8.80 program is already advanced because if the data to be processed is not distributed normally, automatically Lisrel 8.80 program will default in RML analysis mode (Siswoyo, 2016). The Robust Maximum Likelihood estimation method is an adjustment of the ML method by adding an asymptotic covariance matrix to correct data abnormalities (Bentler, 2006).

With the Lisrel 8.8 data processing tool, the goodness of fit overall model test of the conceptual model results in the confirmatory factor analysis path diagram in Figure 1.

To measure the goodness of fit index (GoF) for use are $p$-value chi-square $(x 2)$, Root Mean Square Error of Approximation (RMSEA) and Comparative Fit Index (CFI) (Kline, 2015). The results of the goodness of fit index (GoF) displayed in the following table.

Table 2 - Output goodness of fit overall model (GoF)

\begin{tabular}{lll}
\hline Index \& Criteria & Output & Remark \\
\hline p-value $\geq 0,05 ;$ means good fit & 0,159 & good fit \\
RMSEA $\leq 0,08 ;$ means good fit & 0,075 & good fit \\
CFI $\geq 0,9 ;$ means good fit & 1,000 & good fit \\
\hline
\end{tabular}

Source: Primary data processed, 2020.

The overall goodness of fit test results indicates that the model is fit displayed in Table 2. The next step is the confirmatory factor analysis to test the observed variables' validity and reliability (manifests/ indicators). Analysis of the validity of the measurement model by examining whether (a) the t-value of the variable observed in the model qualifies well, i.e., $\geq$ 1.96 and (b) standardized loading factors $\geq 0.50$ the related variables can be categorized as significant (Hair et al., 2010). Furthermore, the measurement model's reliability analysis calculates the Composite Reliability (CR) value of the processing of standardized loading factors and variance errors. Good reliability criteria if CR $\geq 0.70$ (Siswoyo, 2016). Data processing results of validity and reliability of observed variables (manifests/ indicators) in Table 3.

Table 3 - Confirmatory factor analysis output

\begin{tabular}{|c|c|c|c|c|c|}
\hline Variable & t-value & Standardized Loading Factor & Error variants & CR & Remark \\
\hline Emotional support (X1) & 12,18 & 0,83 & 0,32 & & Valid \& Reliable \\
\hline Instrumental support (X2) & 12,66 & 0,85 & 0,28 & 09 & Valid \& Reliable \\
\hline Informational support (X3) & 12,23 & 0,83 & 0,31 & & Valid \& Reliable \\
\hline Appraisal support (X4) & 12,65 & 0,96 & 0,07 & & Valid \& Reliable \\
\hline
\end{tabular}

Source: Primary data processed, 2020.

\section{DISCUSSION OF RESULTS} outlined:

Finally, based on the results of the study can be discussed, several hypothetical tests

The discussion of hypotheses 1 . The t-value $=12.18 \geq 1.96$, which means it has a positive and significant effect; and loading factor 0.83 and CR 0,92. It proves that emotional support is a valid and reliable determinant of social support for workers with disabilities. The result follows the opinion ((Deutsch \& House, 1983; Fleury et al., 2009; Lysaght et al., 2012). When people with disabilities feel empathy, care, and attention from others, they will not feel alone in facing problems or difficulties to bring their strength to overcome the difficulties they face. 
The discussion of hypotheses 2 . The t-value $=12.66 \geq 1.96$, which means it has a positive and significant effect; and loading factor 0.85 and $C R \quad 0,92$. It proves that instrumental support is a valid and reliable determining indicator of the social support for workers with disabilities. The result follows the opinion ((Deutsch \& House, 1983; Fleury et al., 2009; Lysaght et al., 2012). Direct assistance in efforts, time, and other tangible aid that others give to individuals.

The discussion of hypotheses 3 . The $\mathrm{t}$-value $=12.23 \geq 1.96$, which means it has a positive and significant effect; and loading factor 0.83 and $C R \quad 0,92$. It proves that informational support is a valid and reliable determining indicator of the social support for workers with disabilities. The result follows the opinion ((Deutsch \& House, 1983; Fleury et al., 2009; Lysaght et al., 2012). The existence of informative support (advice, instructions, suggestions, or responses) makes it easier for individuals to expand their thinking or outlook on a problem. So that individuals can have many alternative solutions and can choose the most effective alternatives.

The discussion of hypotheses 4 . The t-value $=12.65 \geq 1.96$, which means it has a positive and significant effect; and loading factor 0.96 and CR 0,92 . It proves that appraisal support is a valid and reliable determining indicator of the social support for workers with disabilities. The result follows the opinion ((Deutsch \& House, 1983; Fleury et al., 2009; Lysaght et al., 2012). Appraisal support includes positive expressions, forward-looking encouragement that others give to individuals, and individuals' favorable comparisons. The presence of positive expressions and encouragement from others helps the individual see his/her strengths, not only focused on his shortcomings alone and moved to progress. Thus, this support allows individuals to have a positive and optimistic attitude.

\section{CONCLUSION}

Based on the results of the study showed that valid and reliable determining indicators of social support for workers with disabilities include: emotional support, instrumental support, informational support, and appraisal support. The role of stakeholders (companies, colleagues, families, communities, governments) to provide various forms of social support is essential for disability equality. This effort is a manifestation of all parties' participation in inclusive development to empower people with disabilities, especially in employment. For further research, it is expected that the need to examine why there is still discrimination against people with disabilities in all aspects and efforts to overcome it.

\section{REFERENCES}

1. Barrera, M. (1986). Distinctions between social support concepts, measures, and models. American Journal of Community Psychology. https://doi.org/10.1007/BF00922627

2. Bentler, P. M. (2006). EQS 6 structural equations program manual. In Los Angeles: BMDP Statistic Software.

3. BPS. (2020). Jawa Tengah Province in Figure: Vol. : 33560.20 (tatistical P. I. and D. Division (ed.)). BPS-Statistics of Jawa Tengah Province; Indonesia.

4. Cassel, J. (1976). The contribution of the social environment to host resistance: The fourth wade hampton frost lecture. American Journal of Epidemiology. https://doi.org/10.1093/oxfordjournals.aje.a112281

5. Cohen, S., \& Wills, T. A. (1985). Stress, Social Support, and the Buffering Hypothesis. In Psychological Bulletin. https://doi.org/10.1037/0033-2909.98.2.310

6. Curran, P. J., West, S. G., \& Finch, J. F. (1996). The Robustness of Test Statistics to Nonnormality and Specification Error in Confirmatory Factor Analysis. Psychological Methods. https://doi.org/10.1037/1082-989X.1.1.16

7. Deutsch, S., \& House, J. S. (1983). Work Stress and Social Support. Contemporary Sociology. https://doi.org/10.2307/2069001

8. Fleury, J., Keller, C., \& Perez, A. (2009). Social Support Theoretical Perspective. Geriatric Nursing. https://doi.org/10.1016/j.gerinurse.2009.02.004 
9. Hair, J. F., Black, W. C., Babin, B. J., \& Anderson, R. E. (2010). Multivariate Data Analysis. In Vectors. https://doi.org/10.1016/j.jpharm.2011.02.019

10. Hastuti, Dewi, R. K., Pramana, R. P., \& Sadaly, H. (2019). Kendala Mewujudkan Pembangunan Inklusif terhadap Penyandang Disabilitas. The SMERU Research Institute. https://www.smeru.or.id/sites/default/files/publication/disabilitaswp_id_0.pdf

11. ILO. (2017). Laporan Akhir - Memetakan Penyandang Disabilitas (PD) di Pasar Tenaga Kerja Indonesia; /Organisasi Perburuhan Internasional (Cetakan Pe). Kantor: ILO.

12. Kanbur, R., \& Rauniyar, G. (2010). Conceptualizing inclusive development: With applications to rural infrastructure and development assistance. Journal of the Asia Pacific Economy. https://doi.org/10.1080/13547860.2010.516163

13. Kossek, E. E., Pichler, S., Bodner, T., \& Hammer, L. B. (2011). Workplace social support and work-family conflict: A meta-analysis clarifying the influence of general and workfamily-specific supervisor and organizational support. Personnel Psychology. https://doi.org/10.1111/j.1744-6570.2011.01211.x

14. Kurtessis, J. N., Eisenberger, R., Ford, M. T., Buffardi, L. C., Stewart, K. A., \& Adis, C. S. (2015). Perceived Organizational Support: A Meta-Analytic Evaluation of Organizational Support Theory. Journal of Management. https://doi.org/10.1177/0149206315575554

15. Langford, I., \& May, T. (1994). Social Research: Issues, Methods and Process. The Statistician. https://doi.org/10.2307/2348595

16. Lysaght, R., Fabrigar, L., Larmour-Trode, S., Stewart, J., \& Friesen, M. (2012). Measuring workplace social support for workers with disability. Journal of Occupational Rehabilitation. https://doi.org/10.1007/s10926-012-9357-1

17. Norbeck, J. S., \& Tilden, V. P. (1983). Life stress, social support, and emotional disequilibrium in complications of pregnancy: A prospective, multivariate study. Journal of Health and Social Behavior. https://doi.org/10.2307/2136301

18. Pérez, V., Alcover, C. M., \& Chambel, M. J. (2015). Job attitudes among workers with disabilities: The importance of family support in addition to organizational support. Work. https://doi.org/10.3233/WOR-141905

19. Peterson, S. J., \& Bredow, T. S. (2011). Middle range theories: Application to nursing research: Third edition. In Middle Range Theories: Application to Nursing Research.

20. Purinami, G., Apsari, N. C., \& Mulyana, N. (2019). Penyandang Disabilitas Dalam Dunia Kerja. Focus : Jurnal Pekerjaan Sosial.

21. Sarason, I. G., Pierce, G. R., \& Sarason, B. R. (1990). Social Support and Interactional Processes: A Triadic Hypothesis. Journal of Social and Personal Relationships. https://doi.org/10.1177/0265407590074006

22. Shumaker, S. A., \& Brownell, A. (1984). Toward a Theory of Social Support: Closing Conceptual Gaps. Journal of Social Issues. https://doi.org/10.1111/j.15404560.1984.tb01105.x

23. Siedlecki, K. L., Salthouse, T. A., Oishi, S., \& Jeswani, S. (2014). The Relationship between Social Support and Subjective Well-Being Across Age. Social Indicators Research. https://doi.org/10.1007/s11205-013-0361-4

24. Siswoyo, H. (2016). Metode SEM Untuk Penelitian Manajemen dengan AMOS 22.00, LISREL 8.80 dan Smart PLS 3.0. In Lisrel, Amos. PT. Intermedia Personalia Utama, Bekasi, Jawa Barat.

25. Stewart, M. J. (1989). Social support intervention studies: a review and prospectus of nursing contributions. International Journal of Nursing Studies.

26. Sugiyono. (2018). Metode Penelitian Kombinasi (mixed Methods). In Alfabet.

27. Swanson, B., Stubbs, D., \& Sheldon, J. (1989). The impact of psychosocial factors on adapting to physical disability: A review of the research literature. Rehabilitation Nursing.

28. Tardy, C. H. (1985). Social support measurement. American Journal of Community Psychology. https://doi.org/10.1007/BF00905728

29. Tilden, V. P., \& Weinert, C. (1987). Social support and the chronically III individual. Nursing Clinics of North America.

30. Zreda, D. Z., \& Majewski, T. (2012). Adaptation of the working environment to the capacities of workers with physical, intellectual and mental disabilities. Medycyna Pracy. 